Balázs S. Elek, Ph.D., Associate Professor

University of Debrecen

Faculty of Law

elek.balazs@law.unideb.hu

\title{
THE CRIMINALIZATION OF POACHING IN HUNGARY
}

Abstract: After 2000, Hungary experienced some extraordinarily unfavorable changes with respect to poaching - in the poachers' style, characteristics, methods and equipment. For a long time the legislation did not recognized the danger of illegal hunting.

Criminological studies led to the codification of poaching law in the Criminal Code in 2012. Previously, it had only been possible to adjudicate and sanction activities related to illegal hunting through different legal frameworks, such as theft or illegal use of weapons. We must also bear in mind that the threat posed by climate change has heightened the importance of laws protecting nature and the environment; consequently, public opinion toward wildlife management and poaching must change.

Keywords: illegal hunting, criminal procedure, punishment, criminalization, environs.

\section{INTRODUCTION}

A relatively high number of studies are published on poaching, illegal hunting, and the criminological characteristics thereof. There is also copious literature concerning poaching's impact on areas of the world where wildlife is endangered. Much less is written about the situation in places like Hungary, where wildlife is abundant. Moreover, poachers in Hungary have different motivations and use different methods than their peers in other countries. Hungary has a reputation for producing some of the top hunting trophies in the world. At times, the main problem for Hungary is the damage that an overpopulation of wildlife inflicts upon farms. 
After 2000, Hungary experienced some extraordinarily unfavorable changes with respect to poaching - in the poachers' style, methods and equipment. Nowadays, poaching gangs in Hungary procure state-of-the-art weapons and technological devices. Gone were the days of the local poacher with a cache of World War II-era weapons in the forest. Over the past 20 years, numerous court cases have alluded to relationships and cooperation between Hungarian and foreign poachers. There is also increasingly clear evidence of relationships between poachers and organized crime groups on both the domestic and international levels.

The growth of the root causes of poaching requires increased vigilance in the battle against illegal hunting. It also necessitates the development of organizational, legal and criminal-law structures aimed at preventing such crimes. This process led to the codification of poaching crimes in 2012. In other words, the Criminal Code was supplemented by legal definitions that are specifically oriented toward poaching. Previously, it had only been possible to adjudicate and sanction activities related to illegal hunting through other legal frameworks, such as theft or illegal use of weapons.

Given the societal changes Hungary has experienced, modern-day poaching merits a much heavier punishment than during the days when people illegally killed game on an occasional basis. Poachers could dodge responsibility for their actions because poaching was considered to be a property-related crime; the old criminal code paid no heed to the specific nature of poaching. We must also recognize that the threat of climate change has heightened the importance of laws protecting nature and the environment; consequently, public opinion toward wildlife management and poaching must change.

"Wildlife crime" is defined as procuring flora and fauna in a manner prohibited by national and international law, as well as the trade or possession of such wildlife. "Conservation criminology," which is a relatively new branch of criminology, may help researchers get to the roots of the illegal wildlife trade and complement the field of conservation biology to help authorities investigate and prosecute poaching activities more effectively. ${ }^{1}$

Effective legal regulations may also increase the chances that the punishments handed down by criminal courts will achieve the goals articulated in the Criminal Code: To dissuade the perpetrator and others from committing crimes of a similar nature. All this may come to pass if the law adequately responds to societal conditions and perpetrators are prevented from getting away with their misdeeds. It is a long-standing principle that one of the most effective tools for discouraging crime is the inevitability of punishment. This is only possible if the law addresses the specific characteristics of poaching - and criminalizes them.

\footnotetext{
${ }^{1}$ José L. Tella, Fernando Hiraldo, "Illegal and Legal Parrot Trade Shows a Long-Term, Cross-Cultural Preference for the Most Attractive Species Increasing Their Risk of Extinction,' PLOS ONE, September 2014, Volume 9, Issue 9, e107546, 1-10.
} 


\section{POACHING AND ITS CONSEQUENCES}

The term "transnational crime" refers to crimes whose prevention, exposition, and direct or indirect impacts affect several countries. This type of crime includes trade in drugs and stolen works of art, terrorism, and the market for endangered species.

The threat of poaching and the trade in endangered species far outweighs the threat of damage that certain endangered species may inflict upon the environment. People who trade in illegal wildlife also deal in other unlawful items such as narcotics and firearms. The theft of natural resources, e.g. wildlife, is a particularly profitable type of transnational crime. Poachers, smugglers, soldiers, guerrillas and organized-crime groups all engage in such activity; ${ }^{2}$ it is so prevalent that it threatens to derail the stability of several developing countries in Africa. ${ }^{3}$

Illegal wildlife traffickers operate in Europe, including Hungary, but poaching poses an entirely different kind of threat. Poaching comprises a series of acts that harms both the law and basic morality; these acts become incorporated into a specific, independent concept. The crime goes far beyond the theft and killing of game. Poaching is a dangerous activity that always opens opportunities for other, more serious crimes such as the illegal use of weapons, acts that threaten life and limb, violence against public authorities, and ultimately terrorism finance. Poaching may promote criminal mentality and may take the form of organized crime as well. ${ }^{4}$

Hungary's law on hunting qualifies "wildlife management" as activities related to the protection of the game stock and its habitat as well as the regulation of wildlife. ${ }^{5}$ Hence anyone who is legally licensed to hunt is required to perpetuate wildlife-management activities. The goal is the development, maintenance and sensible exploitation of an adequate game supply, which must be achieved in harmony with land- and forest-management plans with due consideration for the environment and conservation. A firm scientific grounding is an essential component of modern wildlife management and hunting. Productive and sophisticated wildlife management is not possible without a sound understanding of the animals' habitat, behavior, biology and living conditions.

${ }^{2}$ C. Venter (2003), “Organized Crime: A perspective from South Africa," in J. Albanese, D. Das, \& A. Verma (eds.), Organised crime: World Perspectives, pp. 379-391, Prentice Hall, Upper Saddle River, NJ

${ }^{3}$ Greg L. Warchol, Linda L. Zupan, Willie Clack, "Transnational Criminality: An analysis of the illegal wildlife market in Southern Africa," International Criminal Justice Review, Volume $13,2003,1-27$

${ }^{4}$ Ruth S. Musgrave, Sara Parker, Miriam Wolok, "The Status Of Poaching In The United States - Are We Protecting Our Wildlife?” Natural Resources Journal, Vol. 33, 977 (1993), 977-1014 (p. 1005)

${ }^{5} 1996$ LV Hungarian Act on the Protection of Wildlife, Wildlife Management, and Hunting (Vtv.) $40 . \S$ 
Poaching can be so widespread that it becomes impossible to implement a wildlife-management plan aimed at increasing the animal population. It is impossible to put a monetary value on Hungary's world-renowned game stock, which frequently yields world-record trophies. According to the best estimates, poachers inflict hundreds of thousands of dollars in damage every year, threatening to destroy the long years of work that went into cultivating Hungary's thriving wildlife supply. The biggest financial losses occur on the big-game preserves where the animals are valued not only for their meat, but also for trophies and for purposes related to genetic science.

Hence the killing and theft of wildlife inflicts economic damage that goes far beyond property and ownership rights.

In certain years, the buck that bore the most valuable antlers has fallen prey to poachers in Hungary. If poachers trap and shoot a roe deer that hunters have spent years feeding, caring for and guarding in hopes of bagging a first-rate trophy when it is grown, or offering it up to a foreign hunter for money, then the hunters will get no return on their labor and knowhow; moreover, they will not be able invest as much in future conservation efforts. The situation is even worse when poachers kill a pregnant animal, or one that has just recently given birth: The poachers not only wipe out a new generation of wildlife, but seriously damage the hunters' interests.

Thus the poacher's utterly surreptitious, illegal and uncontrollable activities not only endanger the game supply and the interests of orderly hunting, they also harm licensed hunters' rights to hunt and manage wildlife, as guaranteed by law. Their snares and traps indiscriminately kill and capture animals unlucky enough to get caught. Even when perpetrators use hunting rifles, they do not kill animals in a professional manner with respect to wildlife management. In most cases, poachers do not know the considerations, principles or rules that must be respected when shooting wildlife.

The management and exploitation of the game stock should also consider whether biological resources are self-restoring, or can be restored by humans. When these resources are destroyed, the cost cannot merely be expressed in monetary terms; it is also necessary to account for collateral damage (reduction of diversity in the ecosystem, aesthetic damages) or the cost of restoring the resource.

Some researchers argue that the number of animals stolen or killed by poachers is about one quarter of the number officially bagged by hunters, even by conservative estimates. ${ }^{6}$ Imagine if this were a car factory where 25 percent of the vehicles simply disappeared.

Clearly, poaching makes it nigh impossible for licensed hunting companies, forestry organizations and other groups to fulfill their obligation to plan and

${ }^{6}$ Sándor Békés, Vadászetika (Hunting Ethics), Mezőgazda Kiadó, Budapest, 2001, 119 
manage resources. Damage caused by poaching may be even harder to calculate than weather-related damage.

Within a given wildlife population, the ratio of individual males to females is called the gender ratio. A major diversion from the natural gender ratio is not desirable, because a higher ratio of females increases the likelihood that the weaker males will be able to reproduce. This creates a frailer animal population and lowers the quality of trophies. An overpopulation of males, meanwhile, may increase the number of injuries incurred during fights between bucks during the mating season.

Through wildlife-management techniques, licensed hunters understand whether males or females need to be culled in a given population. Since poachers are unaware of such facts, or ignore them, their interference can cause serious damage.

Poaching may upset a species' gender ratio, which poses real dangers to the species' capacity to reproduce and may affect its social structure as well. It also has the effect of reducing the species' competitive ability. ${ }^{7}$

The various age ratios are called the population's age distribution. As a general rule, the greater restrictions wildlife managers place on shooting young animals, the younger the average age of the population. This highlights the importance of reducing numbers in the younger age groups. Nonetheless, it is necessary to be careful with the planned number of killings from a given brood, because it is impossible to precisely calculate the rate of non-hunting related deaths. Hence it is prudent to plan a relatively small number of baggings in the one-year old animal population, then to adjust the number the next year in line with springtime population estimates.

Thus poachers inhibit the development of the population's age structure with each careless rifle shot or use of a snare that ignores professional considerations. The law requires all hunters to present their bagged red deer, fallow deer, antlers or wild sheep horns within 30 days of the end of the applicable hunting season to the relevant authorities for purposes of awarding trophies. A similar rule exists for wild boar horns that are longer than 16 centimeters. The hunting authority issues a certificate, and licensed hunters can only acquire the right to a trophy in possession of this certificate. This rule also applies to trophies from wildlife that dies from causes not related to hunting. ${ }^{8}$ Since the hunting authority cannot award trophies for animals bagged by poachers, they cannot assess the quality of the game stock and do not know what interventionary measures need to be taken.

The essence of hunting does not lie in success. Humankind could easily annihilate the majority of animal species, but people restrain themselves and

\footnotetext{
${ }^{7}$ Samrat Mondol, Celia R. Mailand, Samuel K. Wasser, "Male biased sex ratio of poached elephants is negatively related to poaching intensity over time," Conserv Genet, (2014) 15, 1259-1263

${ }^{8}$ Vtv. 73-74. $\S$
} 
limit their destructive power. Whether they like it or not, people who want to hunt must grant their prey an opportunity to escape. If they fail to do this, they will exterminate wildlife - and the sport of hunting along with it. The poacher, on the other hand, is after momentary gratification. He is not interested in protecting hunting's sustainability and pays little heed to it.

Participation in wildlife management and hunting requires the prevalence of interests related to conservation - sustainable use, meaning sustainability based upon the biological diversity of huntable species that live in the wild. Hunting of different species of game is only possible to the extent that it does not endanger the animal population's natural diversity and sustainability. ${ }^{9}$

The provisions of Hungary's law on hunting sets the standards for defining which species (game) are huntable, determining the length of the hunting season and the need to impose bans on hunting.

The hunter plays a decidedly positive role in preventing the overpopulation of wildlife in a manner that simulates natural selection (in the absence of big predators.) Undoubtedly, the establishment of hunting seasons is a long-term interest for hunters - one that goes hand-in-hand with natural conservation.

Hunting can only be conducted in open nature. A well-maintained hunting grounds is an ideal place to live for the entire animal kingdom. Caring for wildlife means maintaining variety of plant life and thickets to protect wild animals. Wildlife management represents a kind of intervention into the natural order, and it has an important role in correcting and sustaining population numbers.

Conservation considerations manifest themselves in regulations on hunting equipment, the length of hunting bans and general rules on wildlife protection. Poachers pay little heed to these conservation-related considerations. The poacher is not known for respecting nature-based wildlife management, legal prohibitions against the hunting of protected species, or the hunting season.

In essence, poaching harms hunting-related conservation values. In this case, it is not only the uninhibited shooting of wildlife during periods when hunting is prohibited. By implementing population regulations, licensed hunting organizations and the various regulatory authorities not only determine the numbers of animals in a given stock, they can have a significant influence over the gene supply of a species in a given habitat. When hunters implement so-called game-supply regulations or shoot an animal as a part of hunting, they influence the population's subsistence and its health status. Hence hunters exert the kind of artificial intervention on the ecological system that is absolutely essential for the subsistence of the wildlife population living in a given habitat and in the preservation of its gene supply. ${ }^{10}$

\footnotetext{
91996 LIII Law on Protecting Natural Resources

10 Tibor Dobos, A természet, védelme és vadászat (Nature, Its Protection and Hunting), Market-Trade, Sopron, 2001, 93-106
} 
The poacher frustrates these wildlife-management and conservation activities, or at least makes them very difficult. He is capable of destroying decades of work by licensed hunters with a few careless shots from his rifle or by laying snares. For this reason, the poacher inflicts damage that goes far beyond the market value of the well-endowed animal he kills. Unfortunately, court proceedings do not always take this intangible damage into account - the damage reflecting the role the felled animal played in the given ecosystem or wildlife-management unit.

The hunter's job is to purge from the population those sickly, weak animals that have been dragged to the lower end of the social hierarchy; this contributes to the improved health of the game stock. Natural population-regulation processes always regenerate such animals. The ratio these animals represent depends on the quality of the habitat, the food supply, the population density of the animals, and social stresses. ${ }^{11}$ The poacher does not perform these functions, does not know about them and is not interested in them.

The poacher lacks a conscientious approach when intervening in the wildlife population. It is not possible to mitigate the harm caused by poachers within one or two years; moreover, it is difficult to express the value of the entire damage in monetary terms.

The abundance of wildlife on Hungary's hunting grounds occupies a very significant place in the complex natural system. Wild animals play a decisive role in sustaining ecological and especially biological balance. Open fields and forests constitute the wildlife population's habitat. The presence of wildlife is an elemental part of the ecosystem. Without wildlife, the habitat becomes impaired; a void develops in the food chain, which causes bioproductivity to decline and leads to the disappearance of other species from the habitat.

Poaching can upset a given region's ecosystem. For instance, the diminishing numbers of elephants in Africa inflicts damage on other flora and fauna. ${ }^{12}$

Similarly, human intervention in the form of field and forest management is a form of conservation. When humans intervene in the life of a given habitat's wildlife population, they must do so conscientiously and responsibly. Through conscientious actions they can regulate the game supply in a manner that guarantees that the environment can support the animals, sustains the population's gene supply, purges (kills off) the weaker members from the population, and ensures the adequate gender ratio for the given species.

Hunting is one of the methods for protecting the natural environment, which includes the animals' habitat.

\footnotetext{
${ }^{11}$ István Heltay (ed.), Vadásziskola (Hunting Guide), second revised edition, Hubertus Vadkereskedelmi Kft./István Heltay, Budapest, 2000, 49

${ }^{12}$ Ranee Khooshie Lal Panjabi, "For Trinkets, Tonics, and Terrorism: International wildlife poaching in the twenty-first century," Georgia Journal of International and Comparative Law, Volume 43, number 1, 2014, 1-92
} 
Hungary is a signatory to numerous international conventions that affirm the close relationship between hunting and conservation..$^{13}$ The European Union has no single policy on hunting and wildlife management, but hunting regulations and the natural environment are affected by several directives and ordinances as well as parts of the Common Agricultural Policy. The legislation's goal is to protect certain species and habitats and to end animal suffering. For this reason, the European Union rules that directly affect hunting are strongly restrictive from a wildlife-management point of view. Hence poachers who break national legal frameworks not only harm conservation interests, but also Hungary's international obligations.

One resolution by the Council of Europe specifically addresses the precept that hunting is a significant part of the economy and that it may have a role in conservation as well. ${ }^{14}$ It establishes that hunting can make a significant contribution to environmental protection by fostering an adequate balance between species and eliminating overpopulation among certain species, which helps prevent the spread of disease and damage to the plant stock. With these interests in mind, the resolution recommends that member states take measures to produce better-trained and better-informed hunters. Naturally, any effort to educate hunters will be for naught if poachers destroy their work.

The hunter respects his prey and follows the written and unwritten rules of hunting. He is well versed in hunting's methods, equipment, protocols and traditions. The poacher, on the other hand, is not interested in whether it is illegal to torture an animal. When killing an animal, humans must ensure that the prey suffers as little as possible. In contrast, the snares laid by poachers condemn the trapped animal to a slow and painful death. Out of humanity, the prey should be killed quickly with a gunshot. The wire traps often laid by poachers do not bring instant death, but a prolonged agony that can involve infection and blood poisoning. If the animal manages to free itself and survives, an infection may paralyze its extremities and render the animal crippled.

A basic rule of hunting is that when a hunter injures an animal, or comes across an animal that is seriously ill for other reasons, it is his duty to chase down the animal and kill it. ${ }^{15}$ A slapdash shot that is fired from too far away makes it more likely that the injured animal will escape; the likelihood of inaccurate shooting is greater for poachers because they try to conceal themselves from public

\footnotetext{
${ }^{13}$ For example, the Ramsar Convention on internationally significant wetlands, (1971), the Washington Convention on international trade in endangered species (1973), the Bonn Convention on the protection of migratory species (1979), the Bern Convention on the conservation of European wildlife and natural habitats (1979), and the Rio Convention on protecting biodiversity among animal species (1992).

${ }^{14}$ Thirty-Ninth Ordinary Session of the Parliamentary Assembly of the Council of Europe, Resolution 882/1987 on the Importance of shooting for Europe's rural regions.

${ }^{15}$ Vtv. 29. § (2) paragraph
} 
view, meaning they often fire from cramped body positions. Since looking for bloody tracks is time-consuming, the poacher does not bother to look for the injured animal; searching for an injured animal would put the poacher at greater risk of getting caught than going after a new quarry.

Poachers often hunt with dogs. In most cases, the dogs they use are not properly trained, which breaks the most basic rules on animal protection and hunting. The hunter is responsible for ensuring that only certified hunting dogs are used to seek out and chase down prey.

On more than one occasion, use of dogs that had not received adequate training has led to the deaths of both the prey and the hound. Animal-protection laws prohibit organizing or holding fights in which animals may suffer injury or death. This prohibition does not apply to certified hunting dogs, which must pass an exam, just like humans. ${ }^{16}$

Poaching also results in dangerous situations in the country's various regions. Since the poacher does not sign up to use official hunting zones, he creates a dangerous situation just by wandering around on the territory. Careless shooting endangers others' lives, puts them at risk for bodily injury, and may damage their property. A gun-toting poacher can often be nervous and flustered. He plans his escape at the very moment he fires a shot and does not have time to stop and think. Typically, he does not respect hunting-safety rules. It is no accident that hunters are required to study accident-prevention methods. These very strict rules naturally do not interest people who are breaking the law.

At nighttime, hunters may approach each other using established sound and flashlight signals. However, poachers do not want to be seen, which creates a dangerous situation.

In case of accident, the basic rule of hunting is that hunters must administer first aid to their injured colleagues and immediately get them to medical care. Poachers, on the other hand, not only have to take care of the injured party; it is also important for them to ensure that no one finds out about their illegal activities. If they take an injured person to a doctor, the doctor has an obligation to report them to police in relation to suspected criminal activity. For this very reason, they do not seek proper medical attention for minor injuries. They utterly ignore rules that make it possible for authorities to re-enact the accident.

Criminals can acquire dangerous equipment from poachers such as automatic rifles and night-vision binoculars.

It is often said that licensed hunters, forestry professionals, environmental security guards and even police try to stay away from the areas where poachers operate out of fear for their own skins. Poachers might attack people who come after them or try to expose them because they do not want to be apprehended or

161998 XXVIII Law on Animal Protection and Decency (Ávt.) 24/B. § (1) paragraph 
face punishment. In a few cases, shooting matches have broken out between true hunters and poachers. ${ }^{17}$

Poaching of certain species endangers the eco-tourism sector. For example, thousands of tourists come to view and photograph rare and protected bird species at Hungary's Hortobágy Plains, a UNESCO World Heritage Site. Similarly, rhino poaching threatens "the reputation, eco-tourism industry, and the public image of South Africa," writes geography professor Elizabeth Lunstrum of York University in Ontario, Canada. ${ }^{18}$

It is clear that poaching can reap many times more profit if poachers cooperate with others. ${ }^{19}$ This crime can bring enormous profit, since there is serious organizational work involved in felling an animal and delivering its carcass or trophy to a buyer, or supplying a restaurant with wild game meat.

Poaching also poses a risk to food safety. Poachers maintain relationships with restaurants as a kilo of black-market meat often costs just a fraction of the market price. This raises issues for public health. Wild meat may contain dangerous pathogens that only trained professionals can detect on the carcass. Before taking the meat to market, trained inspectors have to examine the carcass; in some cases, a state-approved veterinarian must also examine it. Strict regulations apply to the transport and storage of wild meat, and poachers cannot uphold these rules.

It must be remembered that populations of several animal species have declined precipitously in Hungary as a direct result of poaching - for instance, the otter population in certain areas. If poaching continues at its current rate, the otter may disappear from those wetlands that are home to Hungary's peerless otter stock. ${ }^{20}$

A few centuries ago, the lynx and the wolf were widespread across the entire European continent. However, the clearing of forests and constant hunting led to the near-total extinction of these animals by the middle of the 20th century in Western Europe and Hungary. Both species have survived in Slovakia; indeed, they gradually began to expand. By the 1980s, news about the growth of Slovakia's lynx and wolf populations often mentioned that the animals were popping up in Hungary as well. Despite blanket legal protection for these animals, poachers continue to pose a great threat to these species.

Poaching represents a real danger to the survival of certain species.

${ }^{17}$ Balázs Elek, Vadászok, halászok a büntetőjog hálójában (Hunters and Fishermen in the Net of the Law), hvgorac kiadó, 2015, 76-92

${ }^{18}$ Elizabeth Lunstrum, "Green Militarization: Anti-Poaching Efforts and the Spatial Contours of Kruger National Park," Annals of the Association of American Geographers, Volume 104, Issue 4, July 2014, 816-832 http://www.tandfonline.com/doi/pdf/10.1080/00045608.2014.912545, published online on 25 Jun 2014

${ }^{19}$ Michael Watson, "Organised Crime and the Environment: the British Experience," European Environmental Law Review, August/September 2005, 207-213

${ }^{20}$ Pál Gera, "Poaching Otters: Why and how are otters being exterminated?" published by the Foundation for Otters, Budapest, 2006, 1-16 


\section{POACHING'S INCLUSION IN THE CRIMINAL CODE}

One of the most important additions to the new Criminal Code that went into force on 1 July 2013 was the separate chapter devoted to crimes against the environment and nature. ${ }^{21}$ The chapter contains a wide variety of legal definitions; however, there are enough similarities between them to allow them to be laid out in a single chapter. These similarities include protection of the environment, nature and their component parts (see impairment to the environment, impairment to nature). This is closely linked to the protection of the living world that plays a role in environmental impairment as well as the protection of animals and plants that play a role in natural impairment. This same factor made it necessary to create the new definitions on illegal hunting and fishing.

Criminal-law protection of the environment and nature is a relatively new area of regulation in both Hungarian and foreign criminal codices. This stems from the fact that for a long time the environment, or behaviors that damage the environment, did not pose the kind of danger to humans that would have necessitated intervention by criminal law. ${ }^{22}$ Lawmakers paid attention to legal scholars' arguments, as the preamble to the law makes clear: "In the present day there is a clear need for the autonomous protection of the environment, and accordingly there is a need for a separate chapter in the law that independently... sets forth definitions of environmental law, in separation from others. The chapter contains a wide variety of definitions; however they have enough similarities between them to allow them to be included in a single chapter. These similarities include protection of the environment and nature as well as their components." 23 In this manner, harming the environment and nature became the primary protected values among the dangers caused by poaching; that is, they were elevated to so-called protected legal interests. Lawmakers also took account of the results of criminological research related to poaching; they carefully studied the relevant monographs and invited researchers to take part in face-to-face discussions at the Justice Ministry during the drafting of the law.

${ }^{21}$ Péter Polt (ed.), "Új Btk. kommentár 5. kötet, különös rész" ("Commentary on the New Criminal Code, Booklet 5, Special Section”) Nemzeti Közszolgálati és Tankönyvkiadó, Budapest, 2013. Chapter 23; Péter Polt, "A környezet és a természet elleni büncselekmények" ("Crimes Against the Environment and Nature"), 9, (Article P of Hungary's Fundamental Law)

${ }^{22}$ László Köhalmy, A környezet védelme a magyar büntetőjogban (Environmental Protection in Hungarian Criminal Law), PhD dissertation, University of Pécs Doctoral School of the Faculty of Law, Pécs, 2010, 106

${ }^{23}$ Supplement to Law I, Crimes Against the Environment and Nature, 2012 C. Law, Chapter XXIII, with preamble by the minister, 1

http://birosag.hu/sites/default/files/allomanyok/project_docs/i.sz_jogszabalyi_melleklet.pdf (accessed on 24 August 2014) 
In the new Criminal Code, lawmakers created a new definition entitled "poaching" that previously did not exist. The prior practice of classifying illegal hunting as a misdemeanor or as theft was not suitable for efficiently combating poaching. ${ }^{24}$

A person commits poaching when

a) he conducts activities aimed at killing or capturing game on hunting grounds without a hunting license or carries out such activities as a hunter on land where he does not have permission to hunt;

b) he kills or captures an animal belonging to a species of game defined in a separate law during a period of time when the hunting of said species is legally prohibited;

c) he conducts activities aimed at killing or capturing animals using prohibited hunting equipment or prohibited hunting methods; conducts such activities on a game preserve where hunting is prohibited; or conducts such activities in relation to vertebrates that are either specially protected or protected. The crime of poaching is punishable by a prison sentence of up to three years. ${ }^{25}$

The poaching law's precepts hold that hunting may only be conducted by people who are licensed, who demonstrate due respect for periods when hunting is prohibited and for hunting bans on game preserves (as spelled out in the laws on wildlife management), and who use only permitted hunting equipment and methods. Certain conceptual components of poaching's legal precepts are defined in the laws on wildlife protection, wildlife management and the law on hunting.

The most significant addition is that hunting without a permit is punishable. Hence poachers can be caught out when they simply step onto hunting grounds with the goal of felling an animal without a permit. Given the changing nature of modern technology, the previous regulations were inappropriate because it was basically impossible to catch out perpetrators when they actually killed an animal. Without catching the perpetrators in the act of killing an animal, it was hardly possible to prove that the crime of theft had been committed.

Hunting is the act of killing or capturing an animal - or an act that is aimed at such - by hunters on hunting grounds, using permitted equipment or birds of prey. ${ }^{26}$ The realization of the act of hunting does not require that the animal actually be killed or captured, because activities aimed killing or capturing already fulfills the definition. This includes when a poacher kills or captures a wounded animal.

The legal definition of hunting is an activity directly aimed at killing animal, which includes the concept of intention, inasmuch as the law qualifies as "hunting" any act directly "intended to result" in the killing of an animal." On an official

${ }^{24}$ Gergely Bárándy, “Állatkínzás jelene és jövője” ("The Present and Future of Animal Torture”), Debreceni Jogi Mühely, 2/2010 (1 April 2010) year VII, number 2, 1-7

${ }^{25}$ Hungarian Criminal Code (Btk.) 245. §

${ }^{26}$ Vtv. 56. § (1) paragraph 
hunting grounds, hunters are entitled to kill game or conduct activities aimed at killing or capturing game if they are guest hunters or contract hunters.

When describing the perpetrators' behavior, the new Criminal Code eschews the expression "hunting" because it is too narrow and subject to misinterpretation. The law prefers the term "killing and capturing." 27

The legal definition of poaching considers nature a protected value. Accordingly, game and its habitat, the preservation of wildlife species in their natural condition for future generations, and the rational exploitation of the wildlife stock are all considered societal interests.

The first instance of poaching is committed by a person who carries out activities aimed at killing or capturing an animal on hunting grounds without a license, or carries out such activities as a hunter on unofficial hunting grounds without permission. In this rule, the law punishes "classic poaching" and also makes it a crime to engage in behavior that aims at killing an animal, even if the animal is not actually killed. A person commits the first instance of poaching if he hunts on any kind of hunting grounds without the proper permission or license; in other words, only "non-hunters" may qualify as perpetrators.

The second instance of poaching is committed by a person who kills or captures an animal during a period when hunting of that animal's species is prohibited by law. In this legal configuration, perpetrators may be either licensed or unlicensed hunters.

Hunting outside of the season always qualifies as hunting during a prohibited period. Hunting is prohibited whenever authorities declare a hunting ban in the interest of protecting game and its habitat. The hunting season is the calendar period during the hunting year when hunting of certain species is allowed. A hunting ban may apply differently to various individual animals within a given species. At the same time, a criminal defense can only be invoked for the actual ban on hunting the given animal.

The law forbids certain hunting methods in the interests of gentlemanly hunting, sportsmanship, and wildlife protection. This relates to the third instance of poaching behavior, which applies to people who kill or capture animals using banned hunting equipment or methods, or hunt on game preserves where hunting is forbidden. In the interest of protecting game and its habitat, it is also forbidden to use banned hunting equipment; banned hunting methods; to hunt during prohibited periods; to hunt on game preserves where hunting in prohibited; and to hunt whenever authorities declare a ban. In accordance with interests related to general animal protection, conservation, and sportsmanship, authorities want to restrict hunting equipment to an adequate framework.

${ }^{27}$ Péter Polt (ed.), "Új Btk. kommentár. 5. kötet, Különös rész" ("Commentary on the New Criminal Code, Booklet 5, Special Section”), 41 
Prohibited hunting equipment includes poison- or explosive-tipped arrows; crossbows; hunting bows and arrows that do not conform with the provisions of the hunting law; firearms equipped with silencers; using grapeshot when hunting for red deer, fallow deer, wild sheep or roe deer; snares, hooks, birdlime and pit traps; and nets that are not selective among animals in their functioning or conditions.

It is also prohibited to capture or kill game using trapping methods or poison listed in European Union regulations. ${ }^{28}$

A person commits the crime of poaching when he conducts activities aimed at killing or capturing an animal - even if he fails to actually bag any game. Previously, such behavior was not punishable.

Currently, the Criminal Code defines the goal of punishment as preventing both the perpetrator and others from committing crimes in the future. "Prevention" means that the punishment must be severe enough to dissuade the perpetrator from committing the crime again. Theoretically, "prevention" achieves its true goal if the punishment alters the perpetrator's personality to the degree that he becomes a law-abiding citizen. Moreover, "dissuasion" is achieved when the perpetrator does not repeat a crime because he fears punishment. Punishment must also serve the goal of dissuading others from committing crimes. Punishment truly serves the purpose of general prevention when it contributes to the solidification of a positive value system among members of society; failing this, punishment can generate a fear of committing crimes among society's members.

The Criminal Code's solution is to threaten people who commit the crime of poaching with three years in prison. At the court's discretion, a substantially milder punishment may be imposed, such as community service or a fine. When poaching is committed in conjunction with another crime, punishment will be meted out in accordance with the severity of the other crimes.

Punishment may include confiscation of poaching equipment and motor vehicles, banishment from the given territory, revocation of hunting permit, loss of permit to keep firearms, and may also involve responsibility for civil restitution.

The term "aggregate crime" means that the perpetrator is accused of several crimes and all of them are adjudicated in a single court proceeding. Typically, poaching is committed alongside crimes such as animal torture, theft, receipt of stolen goods, money laundering, abuse of firearms or munitions, damage to nature, abuse of harmful items of public consumption, distribution of poor-quality products, violation of waste-management rules, and violation of rules on preventing epidemics.

A perpetrator may be accused of both poaching and theft if he takes the killed or captured animal, since the poaching was successful.

${ }^{28}$ See Council regulation 3254/1991/EGK 
If a poacher's quarry is protected or specially protected, then the crime of "damage to nature" may be established. This crime must be established if the perpetrator obtains, keeps, distributes, harms, kills, brings into the country, takes out of the country, transports or trades a protected or specially protected animal during the course of hunting or fishing. ${ }^{29}$

Another crime that may be prosecuted alongside poaching is the abuse of firearms or munitions, if the perpetrator carries out his activities using a weapon without a permit.

When organized criminal groups are involved, the income earned through illegal hunting and fishing may be so great that the perpetrators have no choice but to launder the money. This means that the money launderer returns the criminally obtained goods to the legal economy and takes measures to ensure that the police or tax authorities are none the wiser. When illegal income from poaching and fishing is added to the ledgers of a seemingly law-abiding enterprise, it often creates insurmountable competition for businesses that operate in the legal economy. These "entrepreneurs" gain a competitive advantage when they obtain part of their capital from crime. ${ }^{30}$

\section{CLOSING THOUGHTS AS THE STRUGGLE BETWEEN LEGAL HUNTERS AND POACHERS CONTINUES ON}

Criminological research on poaching in Hungary highlighted the need to change the rules in the Criminal Code in tandem with the changes in the reasons, equipment and methods of poaching, along with changes in the types of people who commit the crime.

I essentially agree with the criminological argument that it is not necessary to stiffen the penalties for poaching, but to increase the likelihood that the poachers will get caught. It is also necessary to raise the inevitability of punishment in order to create an effective deterrent.

In addition to amending the law, it is also important to intensify efforts to expose poaching and to shed light on a greater number of cases. The new Criminal Code that went into force a few years ago in Hungary has already succeeded in raising the number of criminal cases. Previously, a great number of criminal proceedings had to be dismissed due to lack of proof, because it was not possible

${ }^{29}$ Hungarian Criminal code 242. §

${ }^{30}$ István László Gál, Bejelentés vagy feljelentés. A pénzmosás és a terrorizmus finanszirozása elleni küzdelemmel kapcsolatos feladatok és kötelezettségek az új Büntetö Törvénykönyv alapján (Notification or Denunciation: Tasks and obligations in the struggle against money laundering and terrorism finance under the new Criminal Code), Penta Unió Education Center, 2013, 5 
to prove that the perpetrators had committed theft or attempted theft; however, it was clear that they had been hunting without a permit.

Amending the law to provide stiffer punishments was just the first step in the struggle against poaching. People who handle criminal proceedings lack even the most basic knowledge in relation to crimes against nature. Changing this will increase the number of cases that are successfully brought to light and provide a suitably efficient criminal-law response so that we can preserve the natural world for our descendants to enjoy.

\section{REFERENCES}

José L. Tella, Fernando Hiraldo, "Illegal and Legal Parrot Trade Shows a Long-Term, Cross-Cultural Preference for the Most Attractive Species Increasing Their Risk of Extinction," PLOS ONE, September 2014, Volume 9, Issue 9, e107546, 1-10.

C. Venter (2003), "Organized Crime: A perspective from South Africa," in J. Albanese, D. Das, \& A. Verma (eds.), Organised crime: World Perspectives, pp. 379-391, Prentice Hall, Upper Saddle River, NJ

Greg L. Warchol, Linda L. Zupan, Willie Clack, "Transnational Criminality: An analysis of the illegal wildlife market in Southern Africa," International Criminal Justice Review, Volume 13, 2003, 1-27

Ruth S. Musgrave, Sara Parker, Miriam Wolok, "The Status Of Poaching In The United States - Are We Protecting Our Wildlife?" Natural Resources Journal, Vol. 33, 977 (1993), 977-1014 (p. 1005)

1996 LV Hungarian Act on the Protection of Wildlife, Wildlife Management, and Hunting (Vtv.) 40.§

Sándor Békés, Vadászetika (Hunting Ethics), Mezőgazda Kiadó, Budapest, 2001, 119

Samrat Mondol, Celia R. Mailand, Samuel K. Wasser, "Male biased sex ratio of poached elephants is negatively related to poaching intensity over time," Conserv Genet, (2014) 15, 1259-1263

1996 LIII Law on Protecting Natural Resources

Tibor Dobos, A természet, védelme és vadászat (Nature, Its Protection and Hunting), Market-Trade, Sopron, 2001, 93-106

István Heltay (ed.), Vadásziskola (Hunting Guide), second revised edition, Hubertus Vadkereskedelmi Kft./István Heltay, Budapest, 2000, 49

Ranee Khooshie Lal Panjabi, "For Trinkets, Tonics, and Terrorism: International wildlife poaching in the twenty-first century," Georgia Journal of International and Comparative Law, Volume 43, number 1, 2014, 1-92

Ramsar Convention on internationally significant wetlands, (1971), the Washington Convention on international trade in endangered species (1973), the Bonn Convention on the protection of migratory species (1979), the Bern Convention on the conservation of European wildlife and natural habitats (1979), and the Rio Convention on protecting biodiversity among animal species (1992). 
Thirty-Ninth Ordinary Session of the Parliamentary Assembly of the Council of Europe, Resolution 882/1987 on the Importance of shooting for Europe's rural regions.

1998 XXVIII Law on Animal Protection and Decency (Ávt.) 24/B. § (1) paragraph Balázs Elek, Vadászok, halászok a büntetöjog hálójában (Hunters and Fishermen in the Net of the Law), hvgorac kiadó, 2015, 76-92

Elizabeth Lunstrum, "Green Militarization: Anti-Poaching Efforts and the Spatial Contours of Kruger National Park," Annals of the Association of American Geographers, Volume 104, Issue 4, July 2014, 816-832 http://www.tandfonline. $\mathrm{com} / \mathrm{doi} / \mathrm{pdf} / 10.1080 / 00045608.2014 .912545$, published online on 25 Jun 2014

Michael Watson, "Organised Crime and the Environment: the British Experience," European Environmental Law Review, August/September 2005, 207-213

Pál Gera, "Poaching Otters: Why and how are otters being exterminated?" published by the Foundation for Otters, Budapest, 2006, 1-16

Péter Polt (ed.), "Új Btk. kommentár 5. kötet, különös rész" ("Commentary on the New Criminal Code, Booklet 5, Special Section") Nemzeti Közszolgálati és Tankönyvkiadó, Budapest, 2013. Chapter 23; Péter Polt, "A környezet és a természet elleni büncselekmények" ("Crimes Against the Environment and Nature"), 9, (Article P of Hungary's Fundamental Law)

László Köhalmy, A környezet védelme a magyar büntetöjogban (Environmental Protection in Hungarian Criminal Law), PhD dissertation, University of Pécs Doctoral School of the Faculty of Law, Pécs, 2010, 106

Supplement to Law I, Crimes Against the Environment and Nature, 2012 C. Law, Chapter XXIII, with preamble by the minister, 1

http://birosag.hu/sites/default/files/allomanyok/project_docs/i.sz_jogszabalyi_melleklet.pdf (accessed on 24 August 2014)

Gergely Bárándy, "Állatkínzás jelene és jövője” ("The Present and Future of Animal Torture"), Debreceni Jogi Mühely, 2/2010 (1 April 2010) year VII, number 2, 1-7 Hungarian Criminal Code (Btk.) 245. §

Péter Polt (ed.), "Új Btk. kommentár. 5. kötet, Különös rész" ("Commentary on the New Criminal Code, Booklet 5, Special Section”), 41

Council regulation 3254/1991/EGK

István László Gál, Bejelentés vagy feljelentés. A pénzmosás és a terrorizmus finanszírozása elleni küzdelemmel kapcsolatos feladatok és kötelezettségek az új Büntetö Törvénykönyv alapján (Notification or Denunciation: Tasks and obligations in the struggle against money laundering and terrorism finance under the new Criminal Code), Penta Unió Education Center, 2013, 5 
Dr Balaž $\check{S}$. Elek, vanredni profesor

Univerzitet u Debrecinu

Pravni fakultet

elek.balazs@law.unideb.hu

\section{Inkriminalizacija krivolova u Mađarskoj}

Sažetak: Na prelazu iz dvadesetog u dvadeset i prvi vek došlo je do izrazito nepovoljnih promena koje se tiču krivolova, kako po pitanju karaktera krivolova, tako i po pitanju sredstava i metoda koje se primenjuju.

U Mađarskoj se dugo nije prepoznala opasnost koju po društvo predstavlja krivolov. Međutim, istraživanja koja su vođena po pitanju krivolova utvrdila su $i$ nadležnim organima skrenula pažnju na opasnosti koje krivolov predstavlja po mađarsko društvo, što je uzrokovalo da se 2012. godine kodifikuju odredbe krivičnog zakona koje se odnose na krivolov. Ranije, naime, krivična dela koja su bila u vezi sa ilegalnim lovom presuđivana su i sankcionisana u okviru drugih zakonskih činjeničnih stanja, kao što su krađa ili zloupotreba vatrenog oružja. Ne treba zaboraviti ni to da se prepoznavanjem opasnosti od klimatskih promena povećao značaj zaštite prirode $i$ životne sredine, što zahteva novi pristup u privređivanju divljači i krivično-pravnom prosuđivanju krivolova.

Ključne reči: krivolov, krivični postupak, kažnjavanje, zaštita životne sredine.

Datum prijema rada: 28.01.2019. 